\title{
Debt-financed public investment in developing countries: Does the efficiency of public investment matter?
}

\author{
Amarachukwu Anthony Anyanwu*
}

\begin{abstract}
This study examines whether government spending efficiency is associated with differential effects of public investment on debt-to-GDP ratio for a panel data consisting of 16 developing countries in AsiaPacific region over the period 2007-2017. Public investment is central to implementing the UN 2030 Agenda for Sustainable Development — but persistent levels of high public debt without sufficient debt-servicing capacity poses a number of serious risks. The empirical results indicate that public investment efficiency moderates debt-to-GDP ratio whereas public investment in the midst of public sector corruption accentuates debt-to-GDP ratio. The results have important policy implications.
\end{abstract}

Keywords: public debt, government spending efficiency, public investment, public sector corruption JEL Classification: E62, H54, 043

\footnotetext{
*Anyanwu was a Consultant with the Macroeconomic Policy and Financing for Development Division, United Nations Economic and Social Commission for Asia and the Pacific, Bangkok, Thailand. Email: amarachukwu.anyanwu@gmail.com
}

\section{Introduction}

Meeting the UN Sustainable Development Goals (SDGs) requires sustained mobilization of large-scale resources. Increased public spending in important areas like health, education and infrastructure is often cited in policy circles as a crucial avenue to close the gap - but this could undermine fiscal and debt sustainability. However, while debt-financed public investment could raise a country's debt ratios, it can also generate higher growth and revenues, leading to lower debt ratio, if debt is used productively.

The IMF and World Bank (IMF-WB) uses debt sustainability analysis framework (DSA) to identify excessive borrowing that undermines macroeconomic stability. The DSA has helped countries to monitor their risks of debt distress, though it has been criticized for various reasons (Buffie et al., 2012). For example, the existing joint World Bank-IMF Debt Sustainability Framework (DSF) does not distinguish debt directed to productive investments. Wyplosz (2007) argued that the IMF-WB DSA analysis does not adequately consider the link between public investment and growth; it does not capture some key factors concerning the structure of a country's economy, such as the absorptive capacity of the country, efficiency of public investment, and the return on infrastructure which have enormous impact on the outcome of public investments. 
Increased public investment may result to reduced output gains if efficiency in the investment process is not enhanced. Public investment efficiency gains can contribute to achieving the Sustainable Development Goals (SDGs) - particularly in developing countries characterized by limited resources. According to a 2017 McKinsey report, there is ample room to improve the effectiveness and efficiency of infrastructure investment. For example, up to 38 percent of global infrastructure investment is not spent productively because of inefficiencies. The efficient provision of public infrastructure can reduce spending by more than $\$ 1$ trillion a year for the same amount of infrastructure delivered - and the savings can help in closing the SDG financing gap.

The link between efficiency and public investment is markedly important in the context of poor governance and rudimentary public investment systems. Public sector corruption is commonly considered as an innate characteristic of the developing world. Corruption alters the whole decisionmaking process connected with public investment projects. Tanzi and Davoodi (2000) assert that corruption can affect investment in different ways; corruption may affect (a) the size of public investment, and (b) the quality of investment decisions and investment projects.

Consequently, the purpose of this paper is to empirically investigate the following two hypotheses: 1 ) The interaction of public investment and government spending efficiency tends to decrease debt ratios. 2) The interaction of public investment and public sector corruption tends to increase debt ratios, ceteris paribus.

This paper is organized as follows. Section 2 introduces issues of public investment, growth and debt ratios. Section 3 discusses related research studies. Section 4 explores the debt composition. Section 5 explains the data and results. Section 6 presents the conclusions.

\section{Public Investment}

Following the work of Delong and Summers (2012) and Abiad et al. (2017), this section presents theoretical framework for understanding the effect of public investment on output growth and public debt and how public investments can raise output and be self-financing in the long run.

An increase in public investment boosts aggregate demand through the short-term fiscal multiplier, and the magnitude varies with the state of the economy (Auerbach and Gorodnichenko, 2013). This, in turn, affects the debt-to-GDP ratio, which could increase or decrease depending on the magnitude of the fiscal multiplier and the elasticity of revenue with respect to output. As demonstrated in Abiad et al. (2017) and Delong and Summers (2012); in the short term, an increase in public investment as a share of potential GDP $(\Delta \mathrm{i})$ (leads to a change in the debt-to-potential GDP ratio $(\Delta \delta)$ given by:

$\Delta \delta=(1-\mu \tau) \Delta \mathrm{I}$. 
In which $\mu$ is the fiscal multiplier and $\tau$ is the marginal tax rate

The efficiency of public investment is central to determining the size of the fiscal multiplier and the elasticity of revenue with respect to output. Inefficiencies in the public investment process, such as poor project selection, implementation, and monitoring, can result in a fraction of public investment turning into productive infrastructure, undermining the long-term output gains (Pritchett 2000).

Public investment efficiency contributes to higher output by increasing the stock of capital. The extent to which increases in public capital can raise output is a key factor in determining the sequence of public debt-to-GDP ratio. Over time, the increase in public capital will affect the debt-to-GDP ratio by affecting annual debt-financing burden, which is equal to the difference between the real government borrowing rate (r) and the GDP growth rate (g) multiply by the initial change in the debt-to-GDP ratio:

$(\mathrm{r}-\mathrm{g}) \Delta \delta=(\mathrm{r}-\mathrm{g})(1-\mu \tau) \Delta \mathrm{i}$

How the financing burden will affect the debt-to-GDP ratio in the long term depends on the parameters of equation (2) and the elasticity of output to public capital, $\varepsilon$. In the long term, an increase in public investment may lead to an increase in output $(\mathrm{Y})$, which will generate long-term future revenues:

$\tau \Delta \mathrm{Y}=\tau \varepsilon y_{0} \Delta \mathrm{i}$

Where $\varepsilon$ is the long-term elasticity of output to public capital and is the initial output-to public capital ratio. Equations (2) and (3) jointly imply that if the returns to public capital (short-term multipliers and the elasticity of output to public capital) are large enough, such that:

$(\mathrm{r}-\mathrm{g})(1-\mu \tau)-\tau \varepsilon y_{o} \Delta \mathrm{I} \leq 0$

Then an increase in public investment will be self-financing.

\section{Related Literature and Studies}

A wide range of empirical literature has emerged over the last two decades showing that the quality of institutions matter for development. Such findings elevated governance as a determinant of economic development. Studies that are directly related to public debt are those that consider the effect of corruption on debt. Kaufmann (2010) points to a strong correlation between corruption and fiscal deficits in industrialized countries; it suggests that if Greece's levels of corruption was the same to Spain, its budget deficit over the last five years would be $2.5 \%$ of GDP rather than $6.5 \%$. Grechyna (2012) builds a model that relates the level of government debt to the degree of corruptness of the public officials in developed economies and finds that public corruption results in higher public debt levels. Gonzalez-Fernandez and Gonzalez-Velasco (2014) used panel data to analyze the relationship between 
the shadow economy and corruption as determinants of public debt and their results find that corruption has positive and significant impacts on regional public debt in Spain.

Debt burdens are of great concern to the developed countries, but the developing country debt crises is of greater concern and a recurrent phenomenon. Jalles (2011) examined the role of corruption in the association of public debt with economic growth for a panel of developing countries over the 19702005 period. Their results conclude that countries with lower corruption are able to use and manage their debt better. Melecky (2012) points out that good public debt management can reduce borrowing costs and curb financial risks but are more likely to appear in countries with good quality institutions. Megersa and Cassimon (2015) studied a sample of 57 developing countries and found that debt is detrimental for growth, however, harm is reduced while controlling for the quality of public sector management. A comprehensive study by Cooray et al. (2017) examined the relationship between corruption and public debt in 106 countries over 1996-2012 and found that increased corruption leads to an increase in public debt.

A similar study by Kim et al. (2017) examined the relationship between public debt and growth across countries over the period 1990-2014 and conclude that the interaction term between public debt and corruption is statistically significant which implies that the effect of public debt on economic growth is influenced by corruption. A recent paper by Benfratello et al. (2018) used data from a large panel of countries over the period 1995-2015 to investigate the effect of corruption on public debt. Overall, the estimates show that corruption increases public debt. A regional study by Njangang (2018) examined the effect of corruption on public debt on a panel of 29 sub-Saharan African countries for the period 2000-2015 and the results show that corruption has a positive effect on public debt.

Less focus has been paid to possible interactions between government spending efficiency, public investment and public debt. This is important because public investment will continue to be fundamental in financing development goals which has the tendency to raise debt ratios. Therefore, addressing spending inefficiencies is critical - countries need to spend not only more, but better. We conjecture that countries could make significant savings through efficiency improvements.

In several countries, increased public investment does not lead to productive capital (Pritchett 1996). A significant proportion of the expected returns from spending on health, education, and infrastructure is lost due to spending inefficiencies. In the area of health, Grigoli and Kapsoli (2018) find that countries with low efficiency index could raise healthy life expectancy by up to five years through addressing inefficiencies. In the area of education, Grigoli (2015) finds that addressing inefficiencies could help increase enrollment by more 30 percentage points in developing countries. In the area of infrastructure, IMF (2015) finds that more than 30 percent of investment is lost through inefficiency with larger losses in developing countries. In addition, cross-country regressions by (IMF 2015) suggests that the quality 
of institutions is the main determinant of public investment efficiency and the efficiency scores are a function of a set of explanatory variables such as: the quality of institutions, measured by control of corruption and regulatory quality. Overall, the estimates show a positive relationship between public investment efficiency and the quality of institutions.

Efficiency refers to the case where public goods and services are provided at the minimum cost. High levels of corruption, for example, may be a cause of public investment inefficiency. This research study is novel attempt to examine the effect of public investment efficiency on debt-to-GDP ratios in selected developing countries in Asia-Pacific countries.

\section{Debt Composition}

Developing countries mobilize part of their resources by borrowing from internal and external sources to finance their development activities. These sources gradually build up the debt stock of the country. Such debt stock demands regular debt servicing, that is, principal and interest payments, which consume scarce resources that can be used for financing development. Excessive borrowing to finance deficits drains the resources of the developing countries through higher cost of servicing debts.

\section{Figure 1}

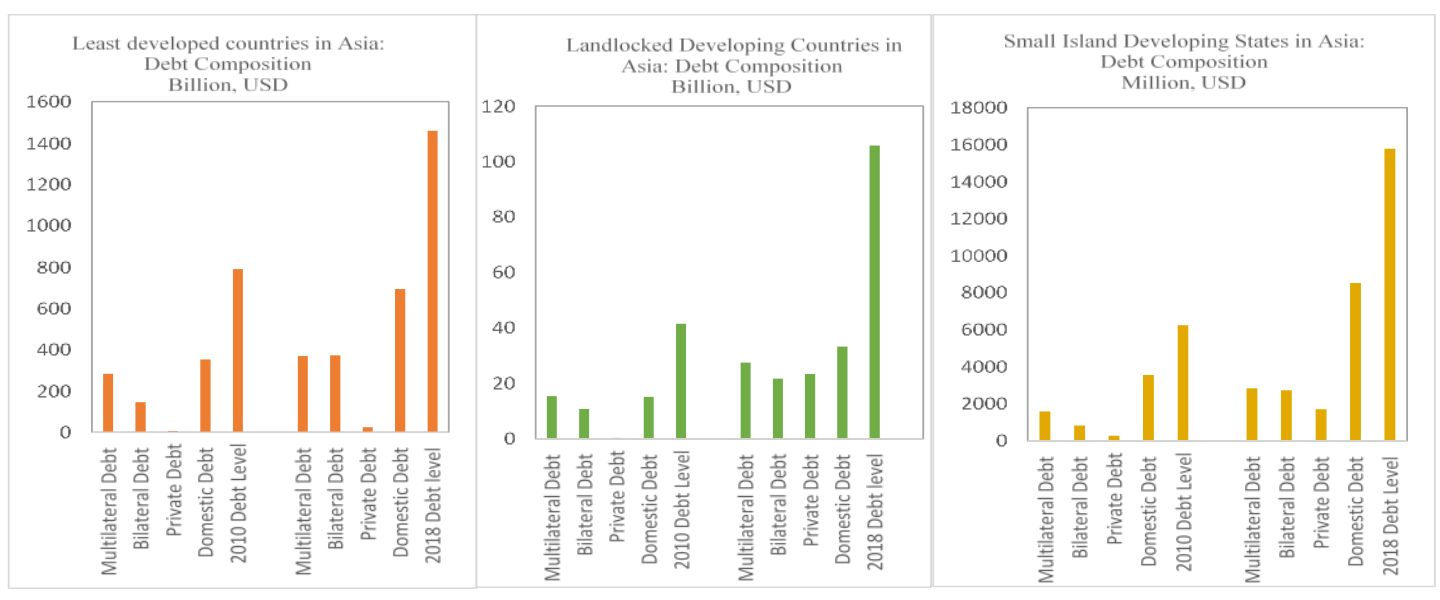

Source: World Bank International Debt Statistics

Figure 1 shows that in least developed countries (LDCs): multilateral debt increased marginally on aggregate; some countries increased their borrowing while others reduced their borrowing. However, bilateral debt doubled; it increased for all countries but heavily dominated by Cambodia, Laos, and Myanmar. Private debt which is commercial borrowing from external private creditors (i.e. international capital market) saw a significant increase as a result of Laos whose outstanding loans jumped from USD 2.3 million in 2010 to 1.8 billion in 2018. Domestic borrowing recorded the highest increment; dominated by Bangladesh which saw its debt ballooned from USD 16 billion to 56 billion. Domestic 
debt accounts for $50 \%$ of the total public debt. Overall, bilateral debt and domestic debt seem to be the increasingly major sources of financing.

In landlocked developing countries (LLDC): multilateral debt increased for all countries except in Laos. Bilateral debt more than doubled on aggregate; only Turkmenistan saw a decrease in bilateral debt. Private debt went up from almost non-existent in 2010 to USD 23 billion in 2018, thanks to Laos, Kazakhstan and Mongolia. Domestic debt increased in all countries dominated by Turkmenistan and Kazakhstan, while Kyrgyzstan and Afghanistan have no domestic debt. External private debt and domestic debt now account for over $50 \%$ of the total public debt.

In small island development states (SIDS): multilateral debt increased on aggregate- Papua New Guinea took the lead from USD 712 million to 1.6 billion. Fiji doubled its multilateral debt to USD 131 million. Bilateral debt increased in all countries and PNG accumulated the largest debt stock at USD 1.2 billion. Samoa, Solomon Islands, Timor Leste, Tonga, and Vanuatu have no external private borrowing; again, PNG recorded the biggest increment from USD 33 million to 1 billion. Domestic debt increased in almost all the countries; Solomon Islands reduced its domestic debt while PNG reported the largest increase with a debt stock of USD 4.9 billion. Domestic debt now accounts for more than $50 \%$ of the total public debt.

On average, multilateral debt seems to be running out of steam as bilateral debt fills the void. However, developing Asia Pacific countries have raised their appetite for commercial debt; not only is debt growing, its structure is changing. The share of commercial—and more costly—debt has increased.

\section{Figure 2}
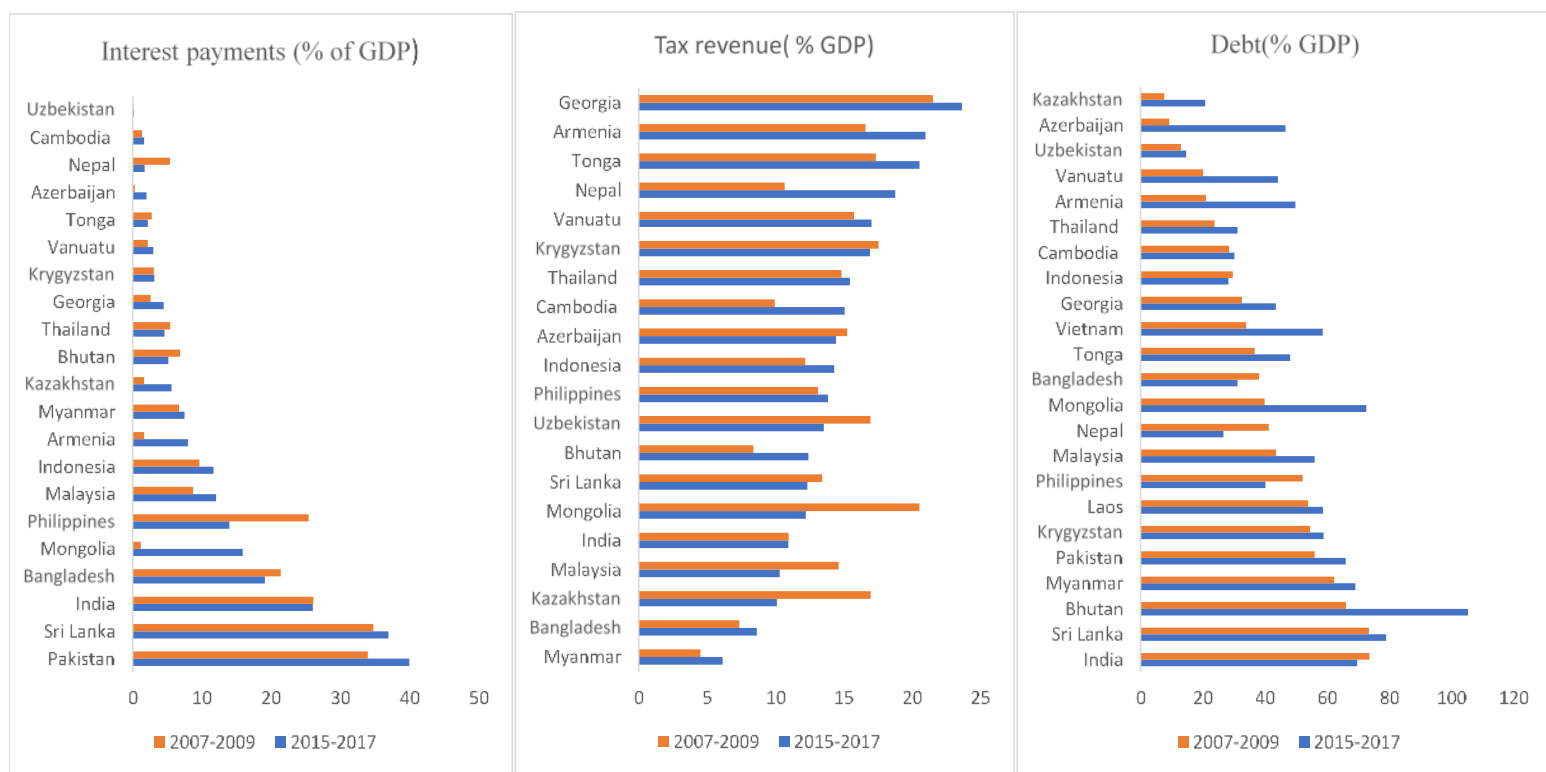

Source: World Bank Development Indicators 
Figure 2 shows debt-to-GDP ratio varies across countries. Bhutan, India, Mongolia, and Sri Lanka have all surpassed the $60 \%$ threshold, while others such as Uzbekistan, Kazakhstan, Indonesia and Nepal have more fiscal space. Countries can have high debt-to GDP ratio and not be in debt distress or at high risk of debt distress. Composition of debt matters. For example, Bhutan has a debt-to-GDP ratio above $100 \%$. Bhutan's interest payment as a percentage of revenue is relatively low at $5 \%$-mainly because its public debt are largely concessional loans. However, interest payments in Sri Lanka is significantly higher at $36 \%$ than Bhutan despite similar tax revenue and higher debt-to-GDP ratio. Sri Lanka's debt composition is markedly different; non-concessional loans in 2006 as \% of GDP was 7\% and increased to 55\% in 2018. Concessional loans exert far less pressure on debt service obligations than commercial loans, and it is the major reason (among others ) why interest payment is high in Sri Lanka.

\section{Figure 3}

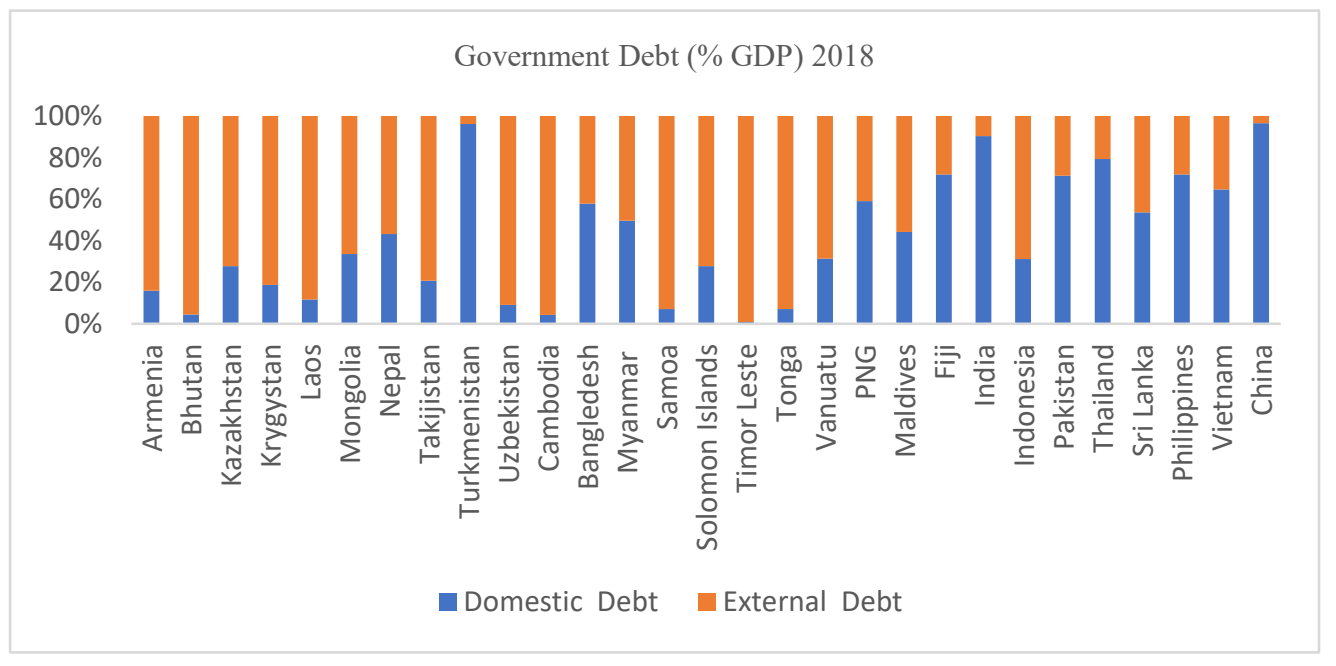

Source: World Bank International Debt Statistics

Debt composition indeed matters for debt sustainability. Figure 3 shows China, Turkmenistan and India have the lowest external debt as a percentage of total government debt while Bhutan, Cambodia and Timor Leste have the highest external debt and vice versa. The choice between external and domestic financing is not the focus of this research. However, in low-income countries, highly concessional external debt is usually a better choice to domestic debt in terms of financial risks and costs, even in the face of a probable devaluation, subject to some caveats. 


\section{Figure 4}

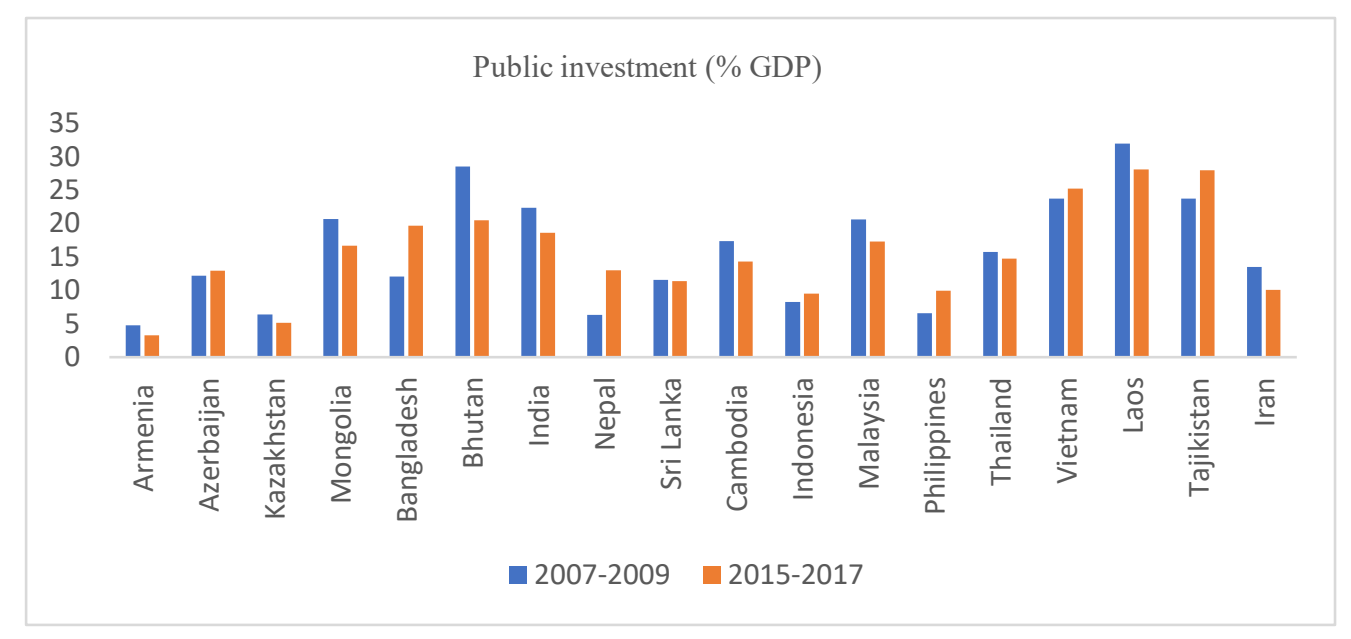

Source: IMF Investment Dataset

Figure 4 shows public investment ranges from $3.3 \%$ to $32 \%$ with overall average of 15.5 per cent. Armenia, Kazakhstan, Nepal, Philippines and Indonesia recorded the lowest values in the period 20072009 while Bhutan, Laos, Vietnam, and Tajikistan recorded the highest values. Public investment fell or remained the same for most of the countries except the case of Bangladesh, Nepal and Philippines -Nepal doubled its public investment. However, it is a good idea to look at public investment in relation to government debt. Armenia's debt to GDP ratio jumped from $21 \%$ to $45 \%$ and within the same period, public investment shrank from 5\% to 3\%. Kazakhstan's debt to GDP ratio went from 9\% to $20 \%$ and within the same period, public investment reduced from $6 \%$ to $5 \%$. Sri Lanka's debt to GDP ratio is almost $80 \%$ but public investment is $12 \%$. In comparison, Laos has a smaller debt to GDP ratio of $59 \%$ but public investment is $28 \%$. The same goes for Vietnam with debt to GDP ratio of $58 \%$ but public investment is $25 \%$. Some countries have low debt to GDP ratio and also low public investment for example Indonesia and Kazakhstan which means there is ample room to scale up public investment. Nonetheless, public investment has generally not been scaled up commensurately with the increase in public debt, and where this is significantly the case, public debt went into government consumption, and/or debt repayments.

\section{Data and Estimation Results}

The data covers the 2007-2017 period for 16 Asia-Pacific countries which are: Armenia, Azerbaijan, Bangladesh, Bhutan Cambodia, Indonesia, India, Kazakhstan, Malaysia, Mongolia, Nepal, Philippines, Sri Lanka, Thailand, Uzbekistan, and Vietnam. The estimation is carried out using panel fixed effects regression ${ }^{1}$. The countries are chosen due to data availability. Time frame is chosen due to limited data for government spending efficiency measure. The dependent variable is the ratio of public debt to GDP, which is measured as the central government debt, total ( $\%$ of GDP). Central government debt refers to

\footnotetext{
${ }^{1}$ The Hausman test lends support to fixed effect over Random effect
} 
the debt by the federal government, while general government debt refers to overall debt, including states and municipalities. The independent variables of interest are the interactions between public investment, government spending efficiency and public sector corruption.

We measure public investment as general government investment ( $\%$ of GDP). We measure government spending efficiency as how efficient is the government in spending public revenue $(1=$ extremely inefficient; 7 = extremely efficient). We measure public sector corruption using the Corruption Perceptions Index (CPI): an index published annually by Transparency International which ranks countries by their perceived levels of public sector corruption, as determined by expert assessments and opinion surveys. The CPI generally defines corruption as the misuse of public power for private benefit. Here the estimate of corruption ranges from 0 (totally corrupt) to 100 (totally not corrupt). The control variables are: GDP per capita growth (annual \%), GDP growth may not translate into growth in GDP per capita due to population growth; trade openness, the sum of imports and exports by GDP; inflation, the percentage change in the GDP deflator; and interest payments, ( $\%$ of revenue).

Table 1 shows the regression results. The effect of public investment on debt to GDP ratio is ambiguous; however, it has no significant effect on the ratio of public debt to GDP in both regressions. More importantly, public investment $\mathrm{x}$ government efficiency has a statistically significant negative effect on the ratio of public debt to GDP. On the other hand, public investment $\mathrm{x}$ public sector corruption has a statistically significant positive effect on the ratio of public debt to GDP. The results imply that the multiplier effect of increased public investment in more corrupt countries is relatively lower whereas the multiplier effect of increased public investment in countries with more efficient public spending is relatively higher. This is somewhat similar to Abiad et al. (2015) results that found public investment shocks lead to significant medium-term reduction in the debt-to-GDP ratio of countries with high public investment efficiency but increase debt-to-GDP ratio in countries with low public investment efficiency in a sample of developed countries. However, our research focused on a sample of developing countries which have relatively weak public investment management institutions — and introduced public corruption index as a robustness check.

The growth of GDP per capita as expected has a statistically significant negative effect on the ratio of public debt to GDP in both regressions. Higher growth lowers the overall debt-to-GDP percentage. Conversely, declines in the long-run economic growth rate drive increases in the debt-to-GDP ratios. The higher the inflation, the lower the ratio of public debt to GDP; inflation can rise and decrease the real value of the domestic debt if debt is denominated in its own currency; however, inflation can also rise and increase the real value of the external debt through exchange rate depreciation. The net effect depends on the debt composition. The higher the interest payments, the higher is the ratio of public debt to GDP; higher interest payments increase the cost of refinancing the stock of existing debt. The more 
open an economy becomes, the higher the ratio of public debt because changes in a country's export and import prices affects the decision to issue new debt. In addition, capital account openness facilitates capital inflows which results in higher debt levels. The regression estimates should be interpreted with caution due to the sample size. However, the central message remains the same: public investment efficiency indeed matters in moderating or accentuating public debt ratios.

Table 1

\begin{tabular}{|c|c|c|c|}
\hline Dependent Variable: & Debt to GDP ratio & & Debt to GDP ratio \\
\hline Independent Variables & Fixed effect (1) & Independent Variables & Fixed effect (2) \\
\hline Lag Debt ratio to GDP & $\begin{array}{l}0.766^{* * *} \\
(0.5216)\end{array}$ & Lag GDP PerCapita Growth & $\begin{array}{l}0.817^{* * *} \\
(0.0828)\end{array}$ \\
\hline Public Investment*Efficiency & $\begin{array}{c}-0.0408^{*} \\
(0.0228)\end{array}$ & $\begin{array}{l}\text { Public } \\
\text { Investment*Corruption }\end{array}$ & $\begin{array}{l}0.0181^{*} \\
(0.0099)\end{array}$ \\
\hline Government Efficiency & $\begin{array}{c}0.6904 \\
(0.3468)\end{array}$ & Corruption & $\begin{array}{c}0.0168 \\
(0.0645)\end{array}$ \\
\hline Public Investment & $\begin{array}{c}1.323 \\
(0.9184)\end{array}$ & Public Investment & $\begin{array}{l}-0.746 \\
(0.491)\end{array}$ \\
\hline GDP Per Capita Growth & $\begin{array}{c}-0.7233 * * * \\
(0.1346)\end{array}$ & GDP Per Capita Growth & $\begin{array}{c}-0.571 * * * \\
(0.0507)\end{array}$ \\
\hline Trade Openness & $\begin{array}{c}0.0581 \\
(0.0639)\end{array}$ & Trade Openness & $\begin{array}{c}0.0323 \\
(0.2445)\end{array}$ \\
\hline Inflation & $\begin{array}{c}-0.295^{* * *} \\
(0.0749)\end{array}$ & Inflation & $\begin{array}{l}-0.257^{* *} \\
(0.0621)\end{array}$ \\
\hline Interest Payment & $\begin{array}{c}0.4188^{* * *} \\
(0.142)\end{array}$ & Interest Payment & $\begin{array}{l}0.154^{*} \\
(0.0916)\end{array}$ \\
\hline Constant & $\begin{array}{l}-15.84 \\
(15.51)\end{array}$ & Constant & $\begin{array}{c}8.67 \\
(9.99)\end{array}$ \\
\hline Time effects & Yes & Time effects & Yes \\
\hline Country fixed effects & Yes & Country fixed effects & Yes \\
\hline Obervations & 149 & Obervations & 150 \\
\hline R-sq & 0.91 & R-sq & 0.95 \\
\hline No. of countries & 16 & No. of countries & 16 \\
\hline
\end{tabular}

\section{Conclusion}

This study examined the effect of public investment efficiency on debt ratios. The empirical results show that public investment efficiency has a statistically significant negative effect on public debt which 
implies that public investment efficiency moderates the positive effect of public investment on debt to GDP ratio. However, when public investment interacts with public sector corruption, the variable becomes positive and statistically significant which supports the claim that public investment in the midst of corruption worsens debt ratios. The research study has important policy implications: improving actions against public sector corruption or raising the efficiency of public investment could help moderate debt ratios.

\section{References}

Abiad, A., D. Furceri, and P. Topalova. 2015. "The Macroeconomic Effects of Public Investment: Evidence from Advanced Economies.” IMF Working Paper 15/95. International Monetary Fund.

Auerbach, Alan, and Yuriy Gorodnichenko. 2013. "Measuring the Output Responses to Fiscal Policy." American Economic Journal: Economic Policy 4 (2): 1-27

Buffie, E., A. Berg, C. Patillo, R. Portillo, and L. F. Zanna. 2012. "Public Investment, Growth and Debt Sustainability: Putting Together the Pieces," IMF, (Washington: International Monetary Fund).

Benfratello, Luigi, Alfredo Del Monte, and Luca Pennacchio. 2018. Corruption and public debt: A crosscountry analysis. Applied Economics Letters 25: 340-44.

Cooray, A., R. Dzhumashev, and F. Schneider. 2017. "How Does Corruption Affect Public Debt? An Empirical Analysis." World Development 90: 115-127.

DeLong, J. Bradford, and Lawrence H. Summers, 2012, Fiscal Policy in a Depressed Economy, Brookings Papers on Economic Activity, 233-297.

Grigoli, Francesco and Kapsoli, Javier. 2018. Waste Not, Want Not: The Efficiency of Health Expenditure in Emerging and Developing Economies. Review of Development Economics, Vol. 22, Issue 1, pp. 384403.

Grigoli, Francesco. 2015. "A Hybrid Approach to Estimating the Efficiency of Public Spending on Education in Emerging and Developing Economies." Applied Economics and Finance 2 (1): 19-32.

González-Fernández, M., González-Velasco, C. (2014). Shadow economy, corruption and public debt in Spain. Journal of Policy Modeling 36, 1101-1117

Grechyna, D., 2012. Public Corruption and Public Debt: Some Empirical Evidence. University of Auckland working paper.

IMF (2015). Making Public Investment More Efficient. Washington DC. http://www.imf.org/external/np/pp/eng/2015/061115.pdf

Jalles, Joa Tovar. 2011. The impact of democracy and corruption on the debt-growth relationship in developing countries. Journal of Economic Development 36: 41-72. 
Kaufmann, D., 2010. Can Corruption Adversely Affect Public Finances in Industrialized Countries. Brookings, April 19.

Kim, E., Ha, Y., \& Kim, S., 2017. Public debt, corruption and sustainable economic growth. Sustainability, $9(3), 433$.

Montes, G. C., and P. C. Paschoal. 2016. "Corruption: What Are the Effects on Government Effectiveness? Empirical Evidence considering Developed and Developing Countries.” Applied Economics Letters 23 (2): 146-150.

Megersa, Kelbesa, and Danny Cassimon. 2015. Public debt, economic growth and public sector management in developing countries: Is there a link? Public Administration and Development 35: 329-4

Melecky, Mertin. 2012. Formulation of public debt management strategies: An empirical study of possible drivers. Economic System 36: 218- 34.

Njangang Ndieupa Henri, 2018. Impact of Corruption on Public Debt: Evidence from Sub-Saharan Africa Countries, American Journal of Economics, Vol. 8 No. 1, pp. 14-17.

Pritchett, Lant. 1996. "Where Has All the Education Gone?” World Bank Policy Research Working Paper No. 1581 .

Pritchett, Lant. 2000. "The Tyranny of Concepts: CUDIE (Cumulated, Depreciated, Investment Effort) Is Not Capital.” Journal of Economic Growth5 (4): 361-84

Tanzi, V., Davoodi, H., 1998, "Roads to Nowhere: How Corruption in Public Investment Hurts Growth", International Monetary Fund Economic Issues, 12: 1-12.

Tanzi, V., Davoodi, H. R., 2000, “Corruption, Growth and Public Finances”, IMF (International Monetary Fund) Working Paper, 182: 1-26.

Wyplosz, Charles, 2007. "Debt sustainability Assessment: The IMF Approach and Alternatives," IHEID Working Paper 03-2007, Economic Sector, The Graduate Institute of International Studies.

Woetzel, Jonathan, Nicklas Garemo, Jan Mischke, Priyanka Kamra, and Robert Palter. 2017. "Bridging Infrastructure Gaps: Has the World Made Progress?” McKinsey Global Institute.

www.mckinsey.com/industries/capital-projects- and infrastructure/our-insights/bridginginfrastructure-gaps-hastheworld-made-progress 


\section{Appendix A}

Definition and sources of variables used in the regression analysis

\begin{tabular}{|c|c|c|}
\hline Variable & Definition & Source \\
\hline \multicolumn{3}{|l|}{ Government } \\
\hline debt & Central government debt (\% of GDP) & IMF's Global Debt Database \\
\hline & General government investment ( $\%$ of & \\
\hline Public & GDP) in constant 2005 international & IMF Investment and Capital \\
\hline investment & dollars & Stock Dataset \\
\hline Corruption & The CPI measures public sector & \\
\hline Perceptions Index & corruption. & Transparency International \\
\hline GDP per & Annual percentage growth rate of GDP per capita & World Bank's World \\
\hline capita growth & based on constant local currency & Development Indicators \\
\hline Government & & World Economic Forum \\
\hline efficiency & Government spending efficiency & \\
\hline Trade & & World Bank's World \\
\hline openness & Exports plus imports as percent of GDP & Development Indicators \\
\hline & & world Bank's World \\
\hline Inflation & GDP deflator (annual \%) & Development Indicators \\
\hline Interest & & World Bank's World \\
\hline payment & Interest payments ( $\%$ of revenue) & Development Indicators \\
\hline
\end{tabular}

Appendix B

Sample of countries used in the regression analysis

\begin{tabular}{|ll|}
\hline \multicolumn{2}{|c|}{ Asia-Pacific countries } \\
\hline Armenia & Malaysia \\
Azerbaijan & Mongolia \\
Bangladesh & Nepal \\
Bhutan & Iran \\
Cambodia & Philippines \\
Indonesia & Sri Lanka \\
India & Thailand \\
Kazakhstan & Vietnam \\
\hline
\end{tabular}




\section{Appendix C}

Summary statistics of variables used in the regression analysis

\begin{tabular}{|llllll|}
\hline VARIABLES & Obs & Mean & Std. Dev & Min & Max \\
\hline Debt \% of GDP & 220 & 41.83 & 20.46 & 5.87 & 114 \\
Public investment as \% GDP & 220 & 15.9 & 7.9 & 2.35 & 37.8 \\
Public sector corruption & 220 & 32 & 10 & 18 & 67 \\
GDP per capita growth & 220 & 4.29 & 3.54 & -13.5 & 24 \\
Trade openness & 220 & 84.6 & 37 & 35 & 200 \\
Inflation & 220 & 7.03 & 7.06 & -18.9 & 39.2 \\
Interest payment as \% & & & & & \\
revenue & 165 & 10.4 & 10.4 & 0.165 & 42.6 \\
Government efficiency & 211 & 3.39 & 0.67 & 1.63 & 5.07 \\
\hline
\end{tabular}

